Livestock Research Corporation,

Um-Benein Station, Sudan.

\title{
MILK PROTEIN POLYMORPHISM IN SUDANESE DAIRY CATTLE BREEDS
}

(With 2 Tables and 2 Figures)

\author{
By \\ Y. HASSAN; G. YOUSIF*; M.T. IBRAHIM** and \\ G. ERHARDT***
}

* The National Ribat University. College of Pharmacy, Khartoum, Sudan. ** Sudan University of Science and Technology, College of Veterinary Medicine and Animal Production, Department of Animal Production, Khartoum North, Sudan.

*** Institute of Animal Breeding and Genetics, Justus-Liebig University, Giessen, Germany.

(Received at 12/10/2010)

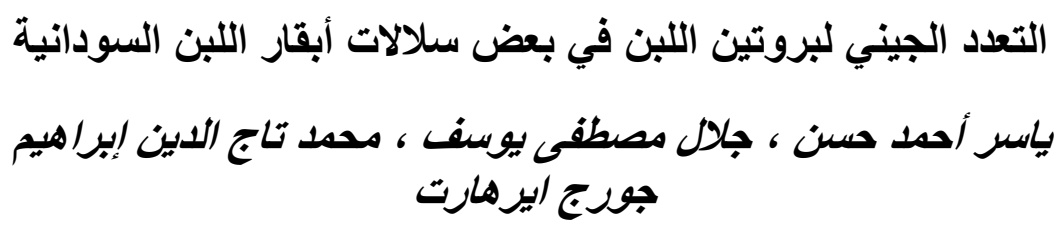

استخدم في هذه الدر اسة عدد 228 رأس من الأبقار (البقارة-الكنانة- البطانة_هجين الفريزيان

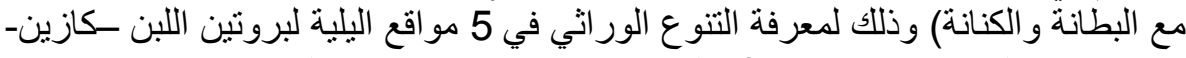
as1-casein (CSN1S1), as2-casein (CSN1S2), $\beta$-casein (CSN2), $\kappa$-casein

(CSN3) $\beta$-lactoglobulin (LGB)

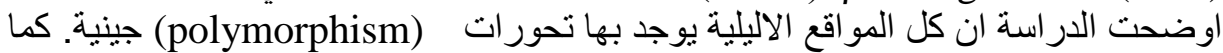

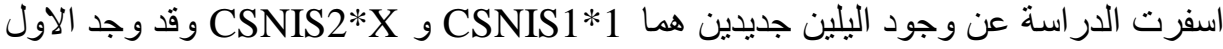
في كل من ابقار البطانة والبقارة بينما وجد الثناني في كل السلالات التي درست

\section{SUMMARY}

The genetic variation at five milk protein loci as1-casein (CSN1S1), as2casein (CSN1S2), $\beta$-casein (CSN2), $\kappa$-casein (CSN3) and $\beta$-lactoglobulin $(L G B)$ was investigated in 228 animals belonging to four dairy populations well adapted to prevailing climatic conditions of Sudan.. Bos indicus (Butana, Kenana and Baggara) and Bos indicus (Kenana or Butana) X Friesian (KBF) were studied using isoelectric focusing technique for loci characterization. All loci were polymorphic and two new variants were detected at CSN1S1 and CSN1S2. The CSN1S1*I 
variant was shown by the Butana and Baggara cattle, while CSN1S2*X variant was observed in all populations under the study. Milk protein loci, being positively selected loci, can also provide information about the occurrence of germplasm particularly useful for breeding strategies and production improvements.

Key words: Milk proteins, casein, lactoglobulin, polymorphism, dairy cattle.

\section{INTRODUCTION}

Studies on milk protein genetic variability dated back almost 50 years ago by detecting bovine $\beta$-lactoglobulin main variants (Aschaffenburg and Drewry, 1957), and were intensively developed during the recent years. In the last 20 years, a new impulse has been given to investigations, not only for the well-known influence of milk protein variants on milk properties (Grosclaude, 1988; Di Stasio and Mariani, 2000). In fact, the bovine milk protein polymorphism have been investigated according to different molecular approaches allowing the DNA typing of known alleles (Medrano and Aguilar-Cordova, 1990; Damiani et al., 1992; David and Deutch, 1992; Barroso et al., 1999; Jann et al., 2002b; Cerriotti et al., 2004), the molecular characterization of some variants (Schlieben et al., 1991; Rando et al., 1998) and the identification of further alleles (Damiani, et al., 1990; Prinzenberg, et al., 1999; Jann et al., 2002a; Ibeagha-Awemu, 2004).

It is known today that there are at least 39 genetic variants of the major six milk protein fractions. These variants occur as consequence of either substitution or deletion of amino acids within their polypeptide chain (Ng Kwai-Hang and Grosclaude, 1992). Interest in studies focusing on milk proteins involves both cosmopolitan and local bovine breeds, including some African populations, which could be better appreciated by a deeper knowledge of their genetic variability. Today, several 'niche' populations exist in Sudan, but they are often difficult to define because of their low productivity and to the marginal social and environmental context in which they have to produce (FAO, 1995). Their survival could be connected to the identification and conservation of peculiar traits of considerable interest in such social and environmental conditions.

During the recent years, the scientific community was attentive to the development of breeding strategies aiming to improve the different productive traits by preserving autochthonous germplasm particularly fitted to the environmental conditions (Moazami-Goudarzi, et al., 2001), 
and also by introducing specialized and well adaptable allochthonous germplasm (Syrstad, 1989; Ehui, et al., 1996). The importance of taking into account milk protein genetic variability in breeding strategies is evident; because of the relationship with milk productive traits mentioned before and supported by recent quantitative trait loci (QTL) linkage analysis (Freyer, et al., 1999; Velmala, et al., 1999).

Milk protein polymorphism in cattle breeds is well characterized mainly in Europe and North America, including endangered populations (Formaggioni, et al. 1999). Data regarding milk protein polymorphism in Zebu populations are scarce (Grosclaude, et al., 1974; Mahe et al., 1999; Prinzenberg and Erhardt 1999; Prinzenberg et al., 1999; Moazami-Goudarzi, et al., 2001). An association of milk protein genotype with the composition and properties of milk could be exploited commercially by using these genotypes as an additional criterion in selecting bulls for artificial insemination. Sudan embraces wealth information on productivity of animals, based on phenotypic values and anthropocentric criteria. Our study aims to characterize genetic variability at protein level in milk protein loci of Butana, Kenana, Bagara ecotypes and (Kenana or Butana) X Friesian crosses. The animals involved among some important (in terms of number, productivity and special characteristics) breeds of Sudanese dairy cattle.

\section{MATERIALS and METHODS}

SAMPLING: A total of 228 animals, 124 Zebu and 104 (zebu x taurus), were randomly chosen for milk collection from $\left(20^{\text {th }}\right.$ December 2004 till $25^{\text {th }}$ January 2005) from different locations. Sampling area and size of each ecotype are shown in Table (1).

Table 1: Breed and data collection information

\begin{tabular}{|l|l|l|l|}
\hline Genus & \multicolumn{1}{|c|}{ Breed } & Number & Sampling Area \\
\hline Bos indicus & Butana & 63 & River Nile State \\
\hline & Kenana & 34 & Blue Nile State \\
\hline Indicus X taurus & Baggara & 27 & Kordofan State \\
\hline $\begin{array}{l}\text { Kenana or Butana) } \\
\text { X Friesian }\end{array}$ & 104 & White Nile State \\
\hline
\end{tabular}

Animals selected for sampling should exhibit typical breed phenotypic characteristics for Bos indicus. Milk samples were taken directly from the animals at the time of milking directly into $5 \mathrm{ml}$ plastic 
containers containing $0.09 \mathrm{mg}$ of sodium azid as preservative, and the samples were transferred directly for refrigerator storage.

\section{Milk Protein Variants Analysis:}

Phenotyping of milk samples was carried out by isoelectric focusing (IEF) technique in ultra-thin Polyacrylamide gels $(265 \times 115 \times 0.03 \mathrm{~mm})$ using the method of Erhardt (1991) with some modification. In detail, the screening gel with $8 \mathrm{M}$ urea containing $0.81 \%$ (w/v) Servalyte $\mathrm{pH} 2.5-5.0 ; 0.648 \%$ (w/v) Pharmalyte $\mathrm{pH} 4.2-4.9$ and $0.29 \%$ Pharmalyte $\mathrm{pH} 5-7$. Samples were then prepared by adding 6 $\mu 1$ skim milk to $50 \mu 1$ sample mix [24 g urea +1.5 Dithioreitol (3\%)] in $50 \mathrm{ml}$ distilled water and mixed well in shaker for 5 minutes. The samples were pepitted and applied $(6 \mu 1$ in round slot applicator) by means of a multiple syringe mm micro-pepittes in front of the anode.

The phenotyes of all systems were identified based on the results of the different comparisons test organized by International Society for Animal genetics (ISAG).

Statistical Analysis:

Allelic frequencies, observed and expected genotype frequencies and deviations from Hardy-Weinberg equilibrium were evaluated by POPGENE software (Raymond and Rousset, 1995).

\section{RESULTS}

Table 2: Allele frequencies in the different ecotypes

\begin{tabular}{|l|c|l|l|l|c|}
\hline \multicolumn{1}{|c|}{ Locus } & Allele & Butana & Kenana & Baggara & KBF \\
\hline & $B$ & 0.2301 & 0.2429 & 0.3889 & 0.6358 \\
\hline CSN1S1 & $C$ & 0.7540 & 0.7571 & 0.5557 & 0.3544 \\
\hline & $D$ & 0.0000 & 0.0000 & 0.0000 & 0.0049 \\
\hline & $I$ & 0.0159 & 0.0000 & 0.0554 & 0.0049 \\
\hline & $A$ & 0.7778 & 0.8088 & 0.8462 & 0.9167 \\
\hline CSN1S2 & $B$ & 0.0159 & 0.0000 & 0.0000 & 0.0000 \\
\hline & $X$ & 0.2063 & 0.1912 & 0.1538 & 0.0833 \\
\hline & $A 1$ & 0.1032 & 0.0286 & 0.0741 & 0.3301 \\
\hline & $A 2$ & 0.8968 & 0.8714 & 0.9259 & 0.6311 \\
\hline CSN2 & $B$ & 0.0000 & 0.1000 & 0.0000 & 0.0388 \\
\hline & $A$ & 0.8175 & 0.7714 & 0.6852 & 0.8750 \\
\hline & $B$ & 0.1825 & 0.2286 & 0.3148 & 0.1202 \\
\hline CSN3 & $E$ & 0.0000 & 0.0000 & 0.0000 & 0.0048 \\
\hline & $A$ & 0.1984 & 0.0429 & 0.0926 & 0.1490 \\
\hline$L G B$ & $B$ & 0.8016 & 0.9571 & 0.9074 & 0.8510 \\
\hline & & & & &
\end{tabular}




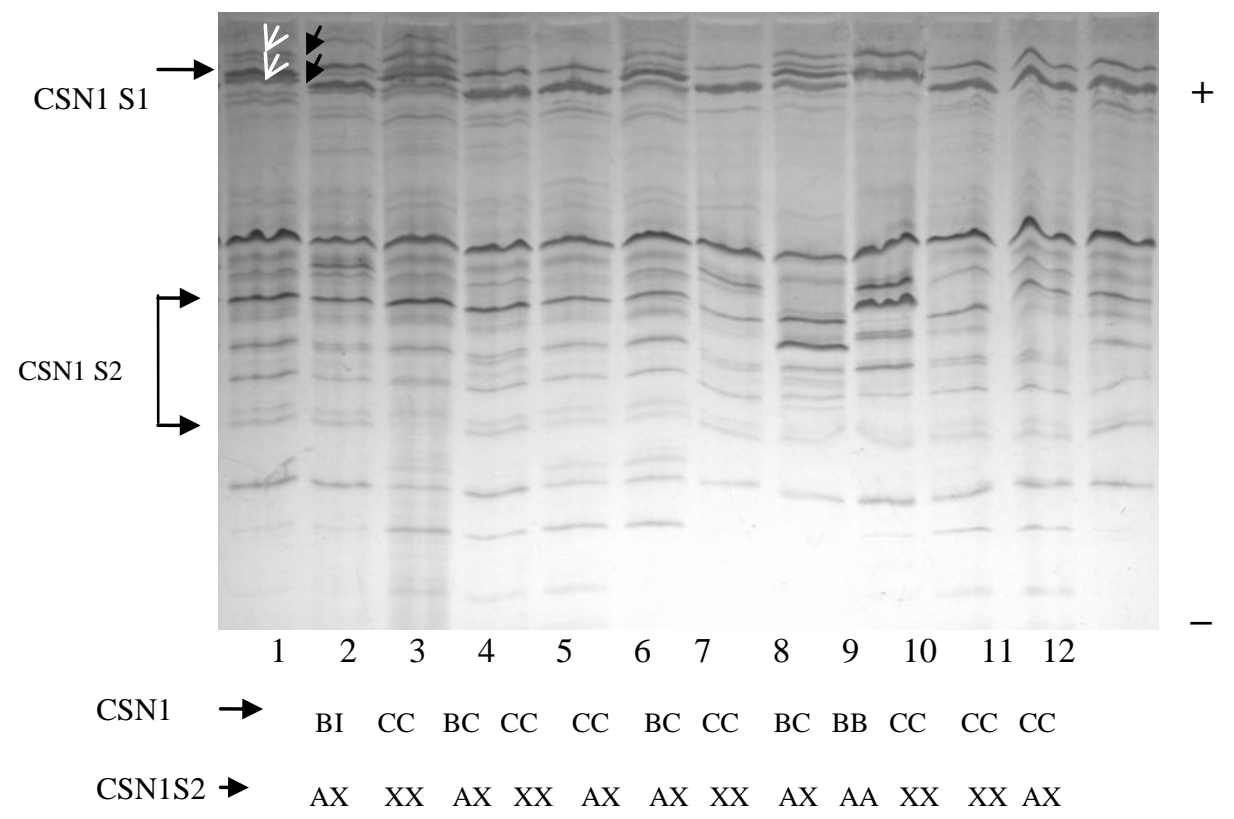

Fig. 1: Isoelectric focussing pattern of cattle milk samples for CSN1S1 and CSN1S2 loci. White arrows indicate the.I.variant.

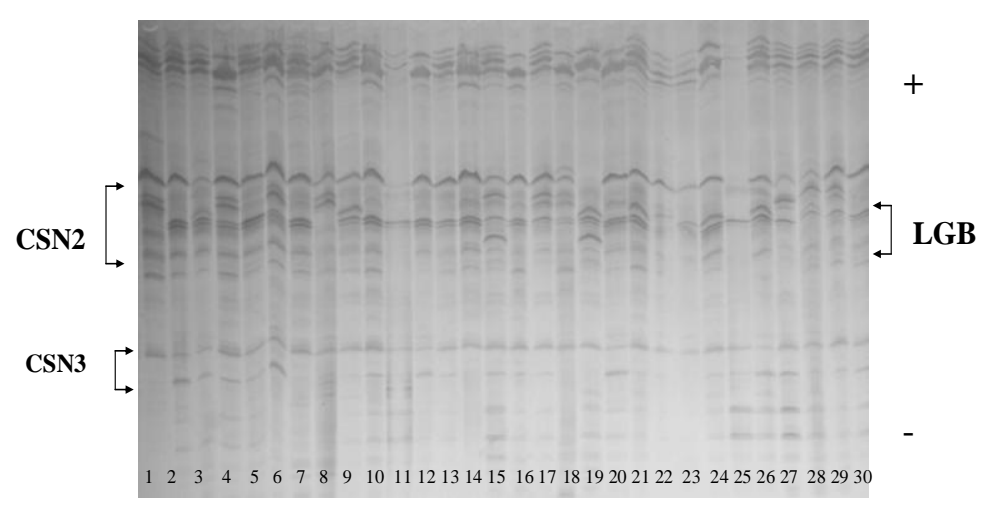

Figure 2: Isoelectric focussing for cattle milk samples.Lanes $5 \& 7$ demonstrate homozygous (A2A2), lanes 9,21,24 \& 26 demonstrate hetrozygote (A1A2), while lanes 15 \& 19 demonstrate A2B \& A1B for CSN2.At CSN3 locus,lanes 2,3,6,12,20,26,27,\&30 demonstrates the hetrozygous $(\mathrm{AB})$, while the remaining lanes demonstrate the homozygous (AA).For LGB, lanes $1 \& 8$ demonstrate the genotpype (AA), lanes $2,3,5,7,9,10,11,12,13,14,16,19,20,21,22,23,24,25,26,30$ demonstrate the genotypes (BB) while lanes 4,6,15,17,18,22,27,28,29 are genotype (AB).

\section{DISCUSSION}


Table (2) showed allelic frequencies at the five loci studied (CSN1S1, CSN1S2, CSN2, CSN3 and LGB). All loci were polymorphic and they revealed a total of 15 alleles (2-4 allele/ locus). The number of alleles for Butana, Kenana, Baggara ecotypes and (Kenana or Butana) X Friesian (KBF) crosses were 12,11, 11 and 14 respectively.

Two electrophoretic bands were seen for the first time at the CSN1S1and CSN1S2 loci. These bands may be two new variants which named CSN1S1*I and CSN1S2*X (Ibeagha-Awemu, 2004) (The CSN1S1*I was observed in Butana, Baggara and (KBF). The presence of this variant in the $(\mathrm{KBF})$ is most probably inherited from the Butana as it is not reported in Friesian. The $C S N 1 S 2 * X$ variant was observed in all breeds studied and again it's presence in the (KBF) crosses may also be inherited from the local ecotypes.

Alleles at the CSN1S1 are characterized by two bands each, a more cathodically located major band and a more anodically located minor band. The minor band of CSNISI*I occurs between the minor bands of $\mathrm{B}$ and $\mathrm{C}$, likewise its major band occurs between the major bands of $\mathrm{B}$ and $\mathrm{C}$ (Figure, 1).

Three bands characterized alleles at CSN1S2. Bands of CSN $1 S 2 * X$ aere more cathodically located than bands of $C S N 1 S 2 * A$ (Figure, 1). Alleles observed at the five milk protein loci were therefore: CSN1S1- B,C,D,I; CSN1S2- A,B,X;CSN2- A1,A2,B;CSN3- A,B,E and $L G B-A, B$. Alleles at $C S N 2, C S N 3$ and $L G B$ loci were clearly separated as shown in Figure (2).

The frequencies of $C S N 1 S 1 * C, C S N 1 S 2 * A, C S N 2 * A 2, C S N 3 * A$ and $L G B^{*} B$ were highest in all the population studied. The new variant CSN1S1*I was present only in Butana, Baggara and Kenana x Friesian breeds at frequencies from 0.0049 to 0.0554 . CSN1S1*D variant is observed only in the cross (KF). This variant might be introduced from the Holstein breed used for upgrading of Kenana cattle.

The Kenana ecotype and $(\mathrm{KBF})$, exhibited Hardy-Weinberg equilibrium $(\mathrm{P}<0.05)$ at the CSN2 locus, as well as for the Butana ecotype at the CSN1S1 locus. Kenana and Baggara ecotypes on the other hand showed equilibrium at the CSN1S2 locus. CSN3 and LGB loci do not conform Hardy-Weinberg equilibrium.

The present work enables to compare these results with previous data obtained by the traditional protein techniques in some African Bos genus (Mahé et al., 1999; Ibeagha, 2004). The allele discrepancies observed in this study can be interpreted, both by genetic drift and open 
breeding system effect. Sudanese cattle population are exposed to active pastoralism and to consequent uncontrolled crossing among populations, with a higher variability within breed and lower variability among breeds than expected.

The detection of milk protein variants through electrophoresis (e.g. PAG-IEF) of milk samples may be limiting in that, not all known variants can be demonstrated (Prinzenberg et al., 1999) and only mature cows can be evaluated. It is however a quick and economic means to simultaneously investigate the presence or absence of already known alleles and the presence of new alleles in a population.

\section{ACKNOWLEDGEMENTS}

Members of Institute of Animal Breeding and Genetics, JustusLiebig University, Giessen, Germany are highly appreciated for their support and laboratory analysis of the samples.

\section{REFERENCES}

Aschaffenburg, $R$. and Drewry, J. (1957): Genetics of the $\beta$ lactoglobulin of cows' milk. Nature 180: 367-378.

Barroso, A.; Dunner, S.; Canon, J., (1999): A multiplex PCR-SSCP test to genotype bovine beta-casein alleles A1, A2, A3, B, and C. Anim.Genet.30: 322-323.

Ceriotti, G.; Marletta, A.; Caroli, A. and Erhardt, G., (2004): Milk protein loci polymorphism in taurine (Bos taurus) and zebu (Bos indicus) populations bred in hot climate. J. Anim. Breed. Genet. 121: 404-425.

Daminani, G.; Ferretti, L.; Rognoni, G. and Sgramella, V. (1990): Restriction Fragment Length Polymorphism analysis of KappaCasein locus in cattle. Anim. Genet. 21: 107-114.

Damiani, G.; Ferretti, L.; Rognoni, G. and Sgaramella, V. (1992): Direct sequencing and bidirectional allele specific polymerase chain reaction of the bovine beta-casein B variant. Anim. Genet. 23: 561-565.

David, V.A. and Deutch, A.H. (1992): Detection of bovine as1-casein genomic variants using the allele-specific polymeryse chain reaction. Anim.Genet. 23:425-429.

Distasio, L. and Mariani, P. (2000): The role of protein polymorphism in the genetic improvement of milk production. Zoot. Nutr. Anim. 26: 69-90.

Ehui, S.K.; Shapiro, B.I. and Yapi-Gnaore, V.C. (1996): Peri-urban 
livestock production and development in sub-saharian Africa: a review of the constraints and opportunities. Proc. VIII Int. Conf. Inst. Trop. Vet. Med. Berlin. 1: 151-163.

Erhardt, G. (1991): Anwendungsmöglichkieten hochauflösender elektrophoretischer Trennverfahren bei tierzüchterischen Fragestllungen. Fleck, Wissenschaftlicher Fachverlag, Niederkleen.

FAO, (1995): L'approvisionnement des villes africaines en lait et produits laitiers. Food and Agricultural Organization of the United Nations (FAO), Rome, Italy.

Formaggioni, P.; Summer, A.; Malacarne, M. and Mariani, P. (1999):

Milk protein polymorphism: detection and diffusion of the genetic variants in Bos Genus. Ann. Fav. Med. Vet. Un. Parma. 12: $127-165$.

Freyer, G.; Liu, Z.; Erhardt, G. and Panicke, L. (1999): Casein polymorphism and relation between milk production traits. J. Anim. Breed. Genet. 116: 87-97.

Grociaude, F.; Mahe, M.F. and Mercier, J.C. (1988): Le polymorphisme genetique des principales lactoprotienes bovines. Relations avec la quantite, la composition et les aptitudes fromageres du lait. INRA Prod. Anim. 1: 5-17.

Grosciaude, F.; Mahe, M.F. and Mercier, J.C. (1974): Comparison du polymorphisme genetique des lactoproteines du Zebu et des bovins. Ann. Genet. Sel.anim. 6: 305-329.

Ibeagha-Awemu, E.M. (2004): Biochemical and molecular genetic characterization of cattle breeds of Cameroon and Nigeria. Ph. D. Thesis. Fachbereich Agrarwissenschaften, der Justus-Liebig University, Germany.

Jann, O.; Ceriotti, G.; Caroli, A. and Erhardt, G. (2002a): A new variant in exon VII of bovine $\beta$-casein gene (CSN2) and its distribution among European cattle breeds. J. Anim. Breed. Genet. 119: 65-68.

Jann, O.; Prinzenberg, E.M.; Brandt, H.; Willams, J.L.; AjmoneMarsan, P.; Zaragoza, P.; Ozbeyaz, C. and Erhardt, G. (2002b): Intragenic haplotypes at the bovine CSN1S1 locus. Archiv für Tierzucht 45: 13-21.

Mahe, M.F.; Miranda, G.; Queval, R.; Bado, A.; Zafindrajona, P.S. and Grosclaude, F. (1999): Genetic polymorphism of milk proteins in African Bos taurus and Bos indicus populations. Characterization of variants $\alpha$ s1-Cn H and $\kappa-\mathrm{Cn}$ J. Genet. Sel. 
Evol. 31: 239-253.

Medrano, J.F. and Aguilar-Cordova, E. (1990): Polymerase chain reaction amplification of bovine $\beta$-lactoglobulin genomic sequences and identification of genetic variants by RFLP analysis. Anim. Biotech. 1: 73-77.

Moazami-Goudarzi, K.; Belemsaga, D.M.A.; Ceriotti, G.; Laloe, D.; Fagbohoun, F.; Kouagou, N.T.; Sidibe, I.; Codjia, V.; Crimella, C.; Grosclaude, F. and Toure, S.M. (2001): Caractérisation de la race bovine Somba á l'aide de marqueurs molécolaires. Revue Elev. Méd. Vet. Pays trop. 54: 129-138.

Ngkwai-Hang, K.F. and Grosclaude, F. (1992): Genetic polymorphism of milk protein. In: Advanced Dairy Chemistry. Vol. 1 Proteins Ed. Fox, P.F. Elsevier Sci. publisher, London, pp. 405-455.

Prinzenberg, E.M. and Erhardt, G. (1999): A new CSN3 allele in Bos indicus cattle is characterized by MspI PCR-RFLP. Anim. Genet. 30: 109-119.

Prinzenberg, E.M.; Krause, I. and Erhardt, G. (1999): SSCP analysis at the bovine CSN3 locus discriminates six alleles corresponding to known protein variants (A, B, C, E, F, G) and three new DNA polymorphisms (H, I, A1). Anim. Biotechnol. 10: 49-62.

Rando, A.; Di Gregorio, P.; Ramunno, L.; Mariani, P.; Fiorella, A.; Senese, C.; Marletta, D. and Masina, P. (1998): Characterization of the CSN1A allele of the bovine as1-casein locus by the insertion of a relict of a long interspersed element. J. Dairy. Sci. 81: 1735-1742.

Raymond, M. and Rousset, F. (1995): GENEPOP (version1.2): population genetics software for exact tests and ecumenicim. J. Hered. 86: 248-249.

Schlieben, S.; Erhardt, G. and Senet, B. (1991): Genotyping of bovine кcasein $(\kappa-\mathrm{CnA}, \kappa-\mathrm{CnB}, \kappa-\mathrm{CnC}, \kappa-\mathrm{CnE})$ following DNA sequence amplification and direct sequencing $\kappa-\mathrm{CnE}$ PCR product. Anim. Genet. 22:333-342.

Syrstad, O. (1989): Dairy cattle cross-breeding in the tropics: performances of secondary cross-bred populations. Livest. Prod. Sci. 23: 97-106.

Velmala, R.J.; Vilkki, H.J.; Elo, K.T.; de Koning, D.J. and Maki-Tanila, A.V. (1999): Asearch for quantitative trait loci for milk productive traits on chromosome 6 in Finish Ayrshire cattle. Anim. Genet.30: 136-143. 